\title{
Synthetic Calcium Phosphate Ceramics as a Potential Treatment for Bisphosphonate-Related Osteonecrosis of the Jaw
}

Siri Paulo ${ }^{1, *(1)}$, Mafalda Laranjo ${ }^{2}\left(\mathbb{C}\right.$, Ana M. Abrantes ${ }^{2}$, João Casalta-Lopes ${ }^{2,3}$, Kathleen Santos ${ }^{2}$, Ana C. Gonçalves ${ }^{4}$, Anabela Baptista Paula ${ }^{5}{ }^{\circledR}$, Carlos Miguel Marto ${ }^{6}{ }^{(0)}$, Ana Bela Sarmento-Ribeiro ${ }^{4}$, Eunice Carrilho ${ }^{5}{ }^{\circ}$, Arménio Serra ${ }^{7}$, Maria F. Botelho ${ }^{2}$ and Manuel M. Ferreira ${ }^{1}$ (D)

1 Institute of Endodontics, Institute for Clinical and Biomedical Research (iCBR), Area of Environment Genetics and Oncobiology (CIMAGO), CNC.IBILI, Faculty of Medicine, University of Coimbra, 3000-548 Coimbra, Portugal; m.mferreira@netcabo.pt

2 Biophysics Institute, Institute for Clinical and Biomedical Research (iCBR), Area of Environment Genetics and Oncobiology (CIMAGO), CNC.IBILI Consortium, Faculty of Medicine, University of Coimbra, 3000-548 Coimbra, Portugal; mafaldalaranjo@gmail.com (M.L.); mabrantes@fmed.uc.pt (A.M.A.); joao.casalta@gmail.com (J.C.-L.); kathleen.santos@hotmail.com (K.S.); mfbotelho@fmed.uc.pt (M.F.B.)

3 Radiation Oncology Department, Coimbra University Hospital Center, 3000-548 Coimbra, Portugal

4 Applied Molecular Biology Unit, Institute for Clinical and Biomedical Research (iCBR), Area of Environment Genetics and Oncobiology (CIMAGO), CNC.IBILI Consortium, Faculty of Medicine, University of Coimbra, 3000-548 Coimbra, Portugal; acc.goncalves@gmail.com (A.C.G.); absarmento@fmed.uc.pt (A.B.S.-R.)

5 Institute of Integrated Clinical Practice, Institute for Clinical and Biomedical Research (iCBR), Area of Environment Genetics and Oncobiology (CIMAGO), CNC.IBILI, Faculty of Medicine, University of Coimbra, 3000-548 Coimbra, Portugal; anabelabppaula@sapo.pt (A.B.P.); eunicecarrilho@gmail.com (E.C.)

6 Institute Experimental Pathology, Institute for Clinical and Biomedical Research (iCBR), Area of Environment Genetics and Oncobiology (CIMAGO), CNC.IBILI, Faculty of Medicine, University of Coimbra, 3000-548 Coimbra, Portugal; mig-marto@hotmail.com

7 Department of Chemical Engineering, Faculty of Science and Technology University of Coimbra, Polo II, Pinhal de Marrocos, 3030-790 Coimbra, Portugal; armenio.serra@gmail.com

* Correspondence: sirivpaulo@gmail.com; Tel.: +351-914-756-654

Received: 14 May 2019; Accepted: 4 June 2019; Published: 6 June 2019

\begin{abstract}
Background: Bisphosphonate-related osteonecrosis of the jaw (BRONJ) is one of the most often seen side effects in patients treated with nitrogen-containing bisphosphonates (BPs), a post-surgical non-healing wound condition. Since calcium phosphate $(\mathrm{CP})$ compounds are able to adsorb zoledronate (ZOL) when used as a drug delivery vehicle, we aimed to verify if these ceramics might have a potential protective effect for soft tissues surrounding surgical osseous wounds. (2) Methods: The chemical reaction between ZOL and CP compounds was evaluated through ultraviolet-visible spectroscopy and elemental analysis. A primary culture of human gingival fibroblasts (HGF) was established as a model to evaluate the cytotoxicity of the association of ZOL $(5-500 \mu \mathrm{M})$ and of ZOL/biphasic calcium phosphates (BCP). Metabolic activity, cell viability, types of cell death, the cell cycle through, and the migration ability of human gingival fibroblasts were evaluated. (3) Results: ZOL was adsorbed by biphasic calcium phosphate compounds in an aqueous solution. The HGF were sensitive to ZOL toxicity; nevertheless, ZOL/BCP showed a significant protective effect regarding metabolic activity, cell viability, and cell migration. (4) Conclusions: BCP interaction with ZOL reduces or abolishes its toxicity in HGF. This finding represents a potential solution for BRONJ in the case of patients undergoing therapy with ZOL.
\end{abstract}

Keywords: biomaterials; biomineralization; bisphosphonate-related osteonecrosis of the jaw; cellular biology; gingival fibroblasts; osteonecrosis; zoledronate 


\section{Introduction}

The use of bisphosphonates (BPs) has dramatically increased over the past few years. BPs offer substantial clinical benefit when an imbalance between osteoblast-mediated bone deposition and osteoclast-mediated bone resorption underlies physiopathology [1]. The main impact of this therapy is the prevention and treatment of cancer-related skeletal complications associated with bone metastases such as pathological fractures, spinal cord compression, tumour induced hypercalcaemia, and severe bone pain [2].

Biochemical interactions between bone microenvironment and cancer cells promote bone destruction and tumour growth [3]. In patients with advanced malignancy, tumour cells invade the bone, yielding skeletal metastases and disrupting bone homeostasis. Osteoclasts and osteoblasts are recruited, leading to the liberation of growth factors and cytokines which can feed back to metastasis growth [4]. The pharmacological effect of BPs is related to their binding to the inorganic component of bone and to their biochemical effect on cells, predominantly osteoclasts [5]. When intravenous BPs are administered, the reduction of activity and number of osteoclasts decreases bone reabsorption, diminishing the malignancy and inhibiting the growth of bone metastasis $[1,6]$.

The propensity of the jaws to bisphosphonate-related osteonecrosis of the jaw (BRONJ) may be due to several anatomical and physiological factors. BPs tend to be highly concentrated in the jaws rather than other skeletal sites because they preferentially deposit in bones with high turnover rates and in sites of significant remodelling $[7,8]$.

Thus, the forces of masticatory function require a rapid bone turnover and can easily induce microfractures that also need remodelling $[9,10]$. Furthermore, unlike other skeletal sites, after surgery or trauma, the wound can be continually exposed to more than 500 different species of microorganisms, resulting in a high susceptibility to contamination and infection [11]. In normal circumstances, the healing of an open bony wound in the presence of normal oral microflora occurs without complication, although, in these cases, when oral microbes reach necrotic bone, they hinder healing $[7,8]$. The prevalence of $\mathrm{BRONJ}$ in cancer patients receiving intravenous zoledronate following tooth extraction ranges from $1.6 \%$ to $14.8 \%$ [12]. Currently there is no effective treatment for BRONJ. The approaches available are mainly conservative (mouth rinses and antibiotics), surgical interventions, and adjuvant strategies, such as hyperbaric oxygen therapy [13].

BRONJ, commonly following dental surgery, has been reported in patients receiving intravenous BPs, particularly zoledronic acid (ZOL), even after the end of the therapy. BPs released from oral bone may impair the migration and growth of oral fibroblasts, inhibiting matrix deposition and the remodelling of oral soft tissues, a critical aspect of wound healing [14]. For the patients, these translate into signs and symptoms such as pain, bone exposure, gingival swelling, soft tissue ulceration, fistular trajectories, tooth mobility, paresthesia, and anesthesia [15].

Presently, there is insufficient evidence to support a particular regimen for the treatment of BRONJ [16]. BP-calcium phosphate (CP) composites are used in the treatment of osteoporosis. The affinity of BPs for hydroxyapatite (HA) explains the basis of this therapy that is used in the treatment of such bone diseases [17]. CP drug delivery systems ensure the controlled release of BPs, which are used due to their anti-resorptive properties [18]. CP ceramics are good delivery systems for drugs and growth factors because of their biocompatibility, variable stoichiometry, surface charge density, functionality, and dissolution properties [17,19].

Considering the above, we hypothesize that $\mathrm{CP}$ ceramics might be used in the treatment of BRONJ. The chemical binding of BPs to CP ceramics might result in the decrease of BP availability in the surgical wound and, therefore, in a lower toxicity. To evaluate our hypothesis in vitro, we established primary cultures of human gingival fibroblasts (HGF) that were used as a model to evaluate BP toxicity and the potential protective effect of biphasic calcium phosphates. 


\section{Materials and Methods}

To establish primary cultures of HGF, the biological material was obtained from human gingival biopsies. The protocol for obtaining such biopsies was approved by the Ethics Committee of the Faculty of Medicine, University of Coimbra (Of Ref. 73-CE-2012). Patients selected for these procedures had indications of gingivectomy and fulfilled the following criteria: Good oral hygiene, non-smokers, and without any known systemic disorders. Before the surgery, patients were informed about the project and chose to participate of their own free will, having read, understood, and signed the respective informed consent.

\subsection{Materials}

Zoledronic acid [(1-hydroxy-2-imidazol-1-yl-1-phosphonoethyl)phosphonic acid] were obtained from Hangzhou Pharm \& Chem Co., Ltd., (Hangzhou, China). Two calcium phosphate ceramics were used; one was constituted of 99.9\% beta-tricalcium phosphate (TCP; Adbone ${ }^{\circledR} \mathrm{TCP}$, Medbone ${ }^{\circledR}$, Medical Devices; Leiria, Portugal), and the other was constituted of $75 \%$ hydroxyapatite (HA) and $25 \%$ biphasic calcium phosphates (BCP; Adbone ${ }^{\circledR}$ BCP, Medbone ${ }^{\circledR}$, Medical Devices, Leiria, Portugal).

\subsection{ZOL-Ceramics Adsorption}

The reaction of ZOL with calcium phosphate ceramics was studied. Aqueous solutions of ZOL in a concentration ranging from 0.1 to $1 \mathrm{mM}$ were prepared. To each $5 \mathrm{~mL}$ of ZOL solutions, $0.02 \mathrm{~g}$ of the TCP, $0.02 \mathrm{~g}$ of the $\mathrm{BCP}$, or $0.06 \mathrm{~g}$ of the $\mathrm{BCP}$ was added, and the mixtures were stirred at room temperature overnight.

Visible/UV spectroscopy (Hitachi U200 spectrophotometer, Chiyoda-ku, Tokyo, Japan) studies were performed to measure ZOL concentration, allowing an evaluation of the incorporation of ZOL in the ceramics. In order to confirm the results obtained, an elemental analysis was performed (Fisons O.CHS Element Analyzer, Thermo Fisher Scientific, Waltham, MA, USA).

\subsection{Primary Cell Cultures}

Primary cultures of HGF were established through adaptation of previous works [20,21]. The biopsies were transported to the laboratory in phosphate-buffered saline (PBS; in mM: 137 $\mathrm{NaCl}, 2.7 \mathrm{KCl}, 10 \mathrm{Na}_{2} \mathrm{HPO}_{4}$, and $1.8 \mathrm{KH}_{2} \mathrm{PO}_{4}[\mathrm{pH} 7.4]$ ), supplemented with $1 \%$ penicillin/streptomycin/ amphotericin B (A-5955, Sigma Aldrich ${ }^{\circledR}$, Israel).

The explants were scraped to remove any epithelial tissue, cut into pieces, and submitted to digestion by incubation with $2 \%$ collagenase type I (Affymetrix ${ }^{\circledR} 13820$, Cleaveland, OH, USA) at 37 ${ }^{\circ} \mathrm{C}$ for $45 \mathrm{~min}$. Subsequently, collagenase was carefully replaced by a solution of $0.25 \%$ trypsin (Gibco ${ }^{\circledR}$ 25200056, Thermo Fisher Scientific, Paisley, Scotland), and digestion continued for $15 \mathrm{~min}$. Afterwards, the fragments were distributed through a petri dish, and a few drops of DMEM (Dulbecco's Modified Eagle's Medium, D-5648, Sigma Aldrich ${ }^{\circledR}$, Saint Louis, MO, USA), supplemented with $10 \%$ fetal bovine serum (FBS, Sigma Aldrich ${ }^{\circledR}$, F7524, Brazil), and 1\% penicillin/streptomycin/amphotericin B were added. The cultures were maintained at $37^{\circ} \mathrm{C}$ in a humidified incubator with $5 \% \mathrm{CO}_{2}$ and filled with a medium after $24 \mathrm{~h}$. Cultures were monitored, and the medium was replaced every three days. Seventh to eighth passages HGF were used in this study.

\subsection{ZOL and $\mathrm{ZOL}-B C P$ Treatment}

The primary cell cultures were plated in 48 -well plates at a density of $2 \times 10^{4}$ cells per well and incubated overnight to allow cell attachment. ZOL was administered at concentrations of 5, 25, 50, 100, and $500 \mu \mathrm{M}$ by dilution in the culture media. In order to evaluate the potential protective effect of biphasic phosphate ceramics (BCP), primary cell cultures were submitted to the ZOL-BCP solutions prepared as described in the ZOL-ceramics adsorption section. Cells were then incubated for periods of 
24, 48, 72, 96, and $120 \mathrm{~h}$ and evaluated according to the studies subsequently described (Cell Citotoxicity, Cell migration studies/Scratch assay, Viability assay, Cell cycle analysis, Types of cell death).

\subsection{Cell Citotoxicity}

The metabolic activity was determined by MTT assay (3-(4,5-dimethylthiazol-2-yl)-2,5-diphenyl tetrazolium bromide; MTT, Sigma Aldrich ${ }^{\circledR}$, USA) [22-24]. Briefly, cell cultures were washed with PBS and incubated with $0.5 \mathrm{mg} \cdot \mathrm{mL}^{-1} \mathrm{MTT}, \mathrm{pH}=7.4$, at $37^{\circ} \mathrm{C}$ for $4 \mathrm{~h}$. Formazan crystals were solubilized in $40 \mathrm{mM}$ hydrochloric acid in isopropanol. Absorbance was evaluated in a Biotek ${ }^{\circledR}$ Synergy HT microplate reader (Biotek Instruments, Winoosky, VT, USA) at $540 \mathrm{~nm}$ with a reference filter of $690 \mathrm{~nm}$. The results allowed us to establish dose-response curves and to calculate $\mathrm{IC}_{50}$ values, the concentration required to inhibit cell proliferation by $50 \%$.

\subsection{Cell Migration Studies/Scratch Assay}

Cells were plated in 6-well plates at a density of $1 \times 10^{6}$ cells per well and incubated overnight to allow cell attachment, as described by Liang et al. [25]. The center of the confluent cell monolayers was scratched, and cell cultures were treated as described. Selected areas were marked and photographed immediately $(0 \mathrm{~h})$ and, subsequently, every $24 \mathrm{~h}$ to record cellular migration into the wounded areas until $120 \mathrm{~h}$, using an ECLIPSE TS100 Nikon microscope (Nikon, Tokyo, Japan) and dedicated software. Cell migration (space between scratch edges) was quantified by measuring the distance between both leading edges using ImageJ software (National Institutes of Health) [26].

\subsection{Viability Assay}

For the evaluation of total protein content, a sulphorhodamine B assay (SRB) was performed [27,28]. Cell cultures were washed with PBS and then fixed with $1 \%$ acetic acid in methanol for $30 \mathrm{~min}$ at $4{ }^{\circ} \mathrm{C}$. Afterwards, $0.4 \%$ SRB (Sigma Aldrich ${ }^{\circledR}$, USA), dissolved in $1 \%$ acetic acid, was added and maintained for $1 \mathrm{~h}$ in the dark, at room temperature. Then, the cells were washed in tap water, and the SRB crystals were dissolved in $10 \mathrm{mM}$ Tris- $\mathrm{NaOH}, \mathrm{pH}$ 10. Absorbance was evaluated in a Biotek ${ }^{\circledR}$ Synergy HT microplate reader at $540 \mathrm{~nm}$.

\subsection{Cell Cycle Analysis}

For the analysis of DNA content, $2 \times 10^{6}$ cells were collected, centrifuged, and fixed with ice-cold $70 \%$ ethanol for $30 \mathrm{~min}$ in the dark. Afterwards, the cells were washed with PBS and incubated with a PI/RNase solution (Immunostep, Salamanca, Spain) for $15 \mathrm{~min}$ at room temperature. Cells were analyzed in the FACSCalibur cytometer (BD Biosciences, San Jose, CA, USA) with an excitation wavelength of $488 \mathrm{~nm}$ and an emission filter of 585/42. Untreated cell cultures and cells treated with 100 and $500 \mu \mathrm{M}$ of ZOL or ZOL/BCP for 96 and $120 \mathrm{~h}$ were analyzed $[29,30]$.

\subsection{Types of Cell Death}

For the analysis of cell viability and types of cell death, $2 \times 10^{6}$ cells were collected, centrifuged, and washed with PBS prior to incubation with the binding buffer, annexin-V and propidium iodide, (Immunostep, Salamanca, Spain) for $15 \mathrm{~min}$, at $4{ }^{\circ} \mathrm{C}$ in the dark. $400 \mathrm{~mL}$ PBS were added, the samples were analyzed in the flow cytometer using an excitation wavelength of $488 \mathrm{~nm}$, and emission filters of 530/30 nm and 585/42 nm were used for annexin- $V$ and for propidium iodide, respectively [31,32]. Untreated cell cultures and cells treated with 100 and $500 \mu \mathrm{M}$ of ZOL or ZOL/BCP for 96 and $120 \mathrm{~h}$ were analyzed.

\subsection{Statistical Analysis}

A statistical analysis was performed using the software IBM SPSS (Version 20, IBM Corporation, New York, NY, USA). Values are expressed using measures of central tendency and dispersion. 
The normality of distributions was evaluated by the Shapiro-Wilk test. The metabolic activity results were compared with the Student $t$ test for an average. IC50 values were compared using the one-factor ANOVA test. A comparison of ZOL and its respective ZOL/BCP metabolic activity and viability values was performed with the Student $t$ test for independent samples if there was there normality of distribution and homogeneity of variances; otherwise, it was performed by the Mann-Whitney test. Regarding the scratch assay, both a types of cell death and cell cycle comparison of the experimental conditions were performed with a one-factor ANOVA test (nonparametric test) or the Kruskal-Wallis test (nonparametric test). All multiple comparisons were corrected according to Bonferroni. A 5\% significance level was considered for all comparisons.

\section{Results}

\subsection{ZOL-Ceramics Adsorption}

The absorbance of the ZOL solutions remained constant up to $120 \mathrm{~h}$. Furthermore, different light exposures and temperatures did not influence these results (data not shown). The presence of phosphate ceramics led to the alteration of the absorbance spectra of the ZOL solutions, as can be observed in Figure 1.

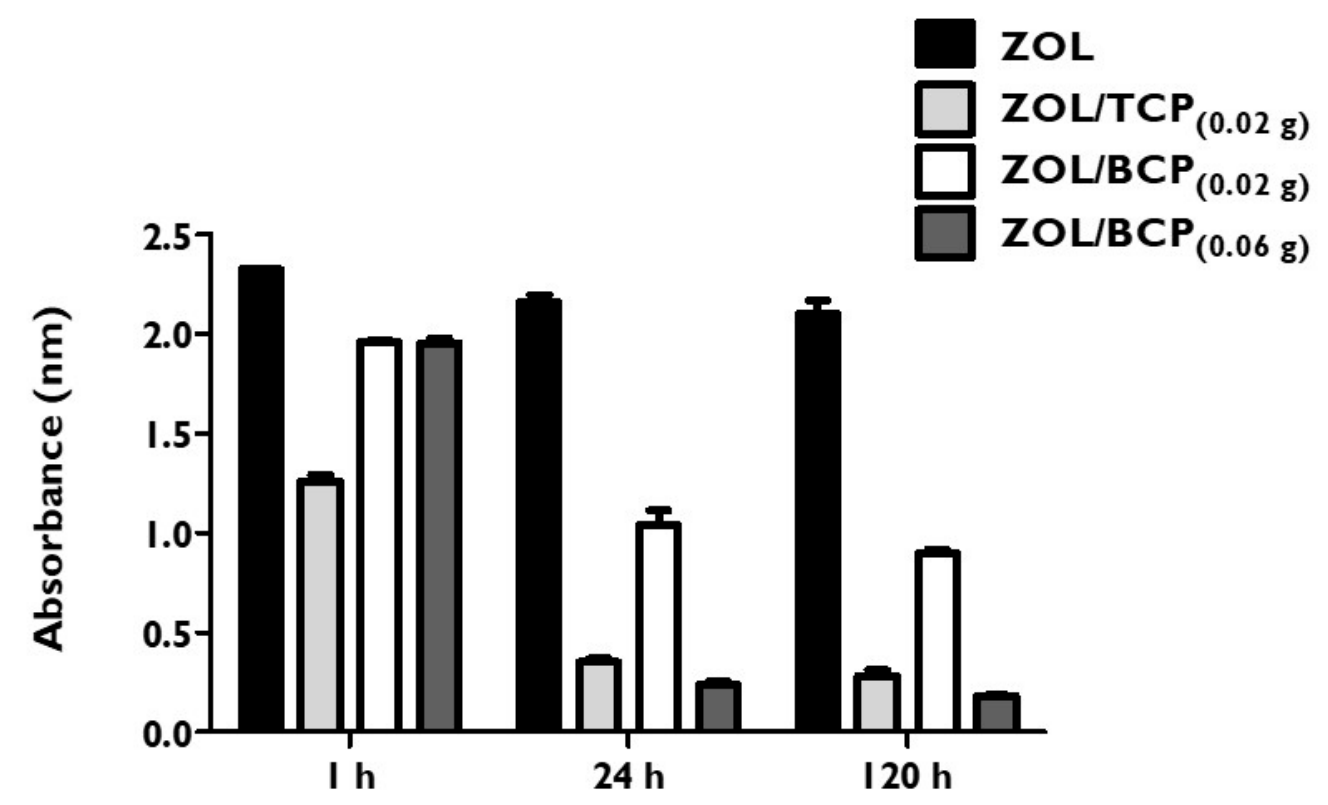

Figure 1. Absorbance (arbitrary units) of the zoledronic acid (ZOL) solution and of the solutions resulting from the mixture with $0.02 \mathrm{~g}$ beta-tricalcium phosphate (TCP), $0.02 \mathrm{~g}$ biphasic calcium phosphates (BCP), and $0.06 \mathrm{~g} \mathrm{BCP}$ after stirring for $1 \mathrm{~h}, 24 \mathrm{~h}$ and $120 \mathrm{~h}$.

Regarding the mixture with TCP, the absorbance decreased $43 \%$ after one hour of stirring relative to the ZOL solution, and it gradually decreased up to $87 \%$ after $120 \mathrm{~h}$. BCP also led to the decrease in absorbance of the ZOL solutions, with the mixture of $0.06 \mathrm{~g}$ being superior, where a fall of $92 \%$ after $120 \mathrm{~h}$ was observed compared to the mixture of $0.02 \mathrm{~g}$, where a decrease of $60 \%$ occurred.

An elemental analysis of BCP samples submitted to ZOL showed the presence of organic atoms, namely nitrogen at a percentage of 0.31 and carbon at a percentage 0.66 (mean values of four trials).

\subsection{Primary Cell Cultures}

The biopsy fragments gave rise to cells with fibroblast morphology, growing attached to the substrate, bipolar, or multipolar and with elongated shapes. About four weeks after the establishment of the cultures, the cells formed a confluent layer exhibiting a spindle form with a central nucleus. Different phases of the primary culture and cell morphology can be observed in Figure 2. 

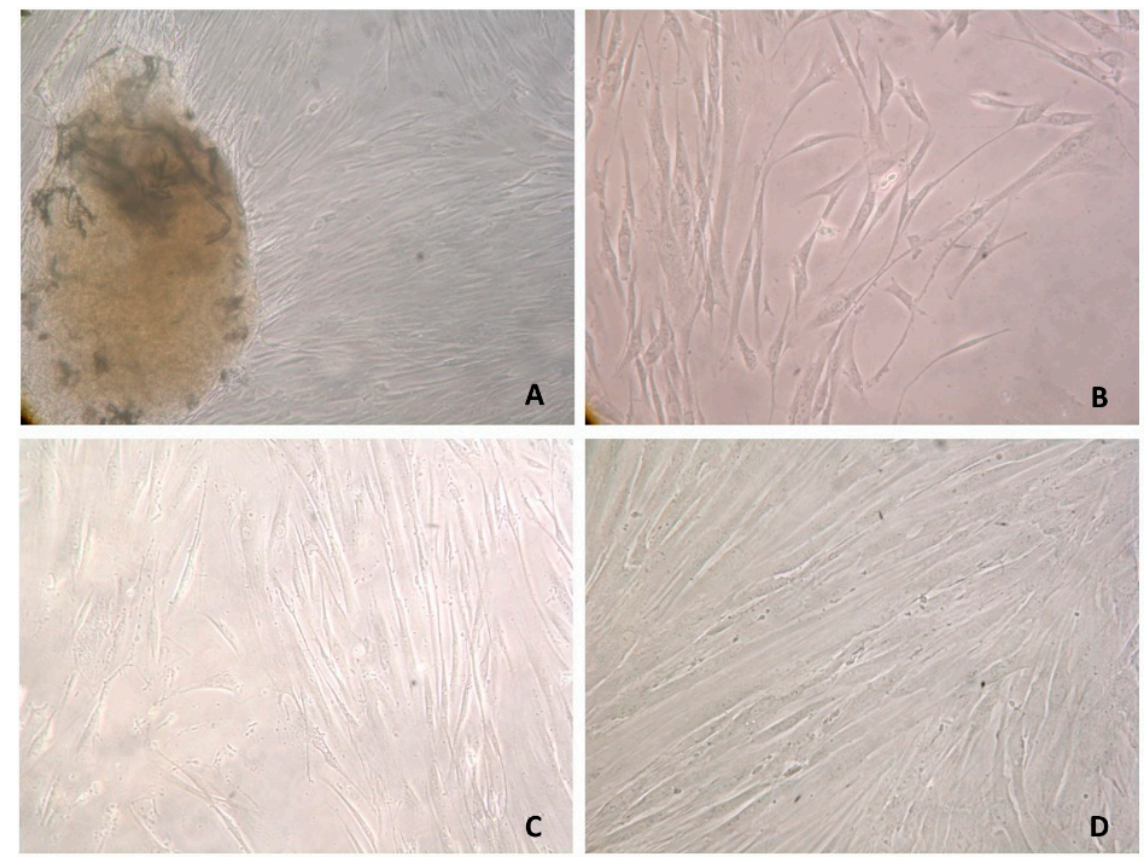

Figure 2. Human gingival fibroblasts (HGF) primary cultures. (A) Cells emerging from an explant, 25 days after culture establishment, 100×. (B) Cells emerging from an explant, 34 days after culture establishment, 100×. (C) HGF, one passage, low confluence, 200×. (D) HGF, tenth passage, high confluence, $400 \times$.

\subsection{ZOL Citotoxicity}

Dose-response curves presented in Figure 3 show the cytotoxicity of ZOL after 24, 48, 72, 96, and $120 \mathrm{~h}$ of incubation.

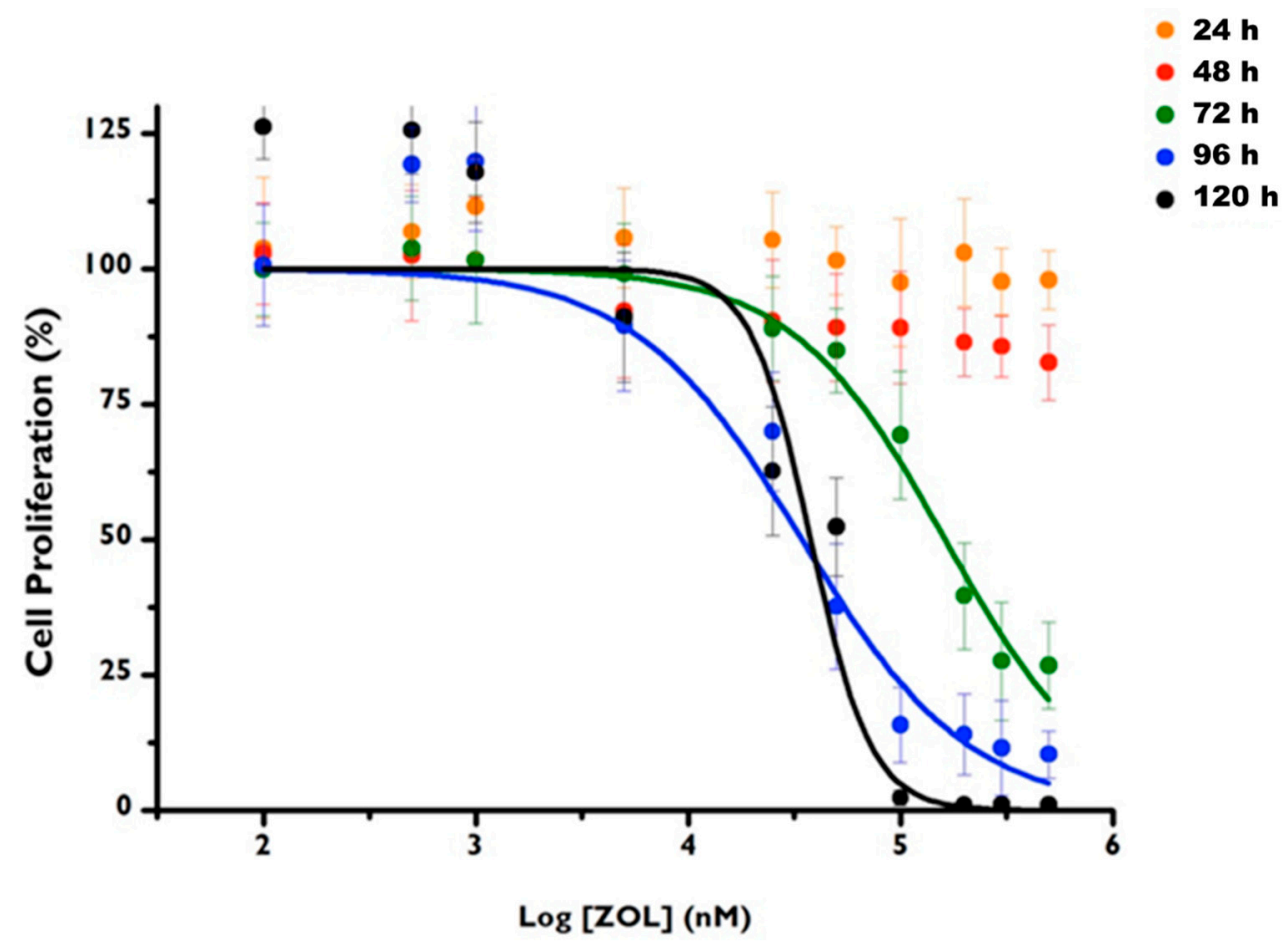

Figure 3. Dose-response curves of HGF primary cell cultures after $24 \mathrm{~h}, 48 \mathrm{~h}, 72 \mathrm{~h}, 96 \mathrm{~h}$ and $120 \mathrm{~h}$ of incubation with ZOL in concentrations ranging from 0.1 to $1 \mathrm{mM}$. The bars represent the mean and standard deviation of at least six tests. 
ZOL cytotoxicity is concentration and time dependent. For the incubation times of 24 and $48 \mathrm{~h}$, it was not possible to calculate the median inhibitory concentration of the cultures (IC50), which was higher than the maximum value tested. However, after 72, 96, and $120 \mathrm{~h}$ of incubation, it was possible to calculate the corresponding IC50 values, which are shown in Table 1, with the respective confidence intervals at $95 \%$. The IC50 value obtained for $72 \mathrm{~h}$ is significantly higher than the values obtained for $96(p=0.016)$ and for $120 \mathrm{~h}(p=0.013)$, with no differences between these times.

Table 1. Median inhibitory concentration of the cultures (IC50) values of human fibroblast primary cultures submitted to ZOL for $72 \mathrm{~h}, 96 \mathrm{~h}$ and $120 \mathrm{~h}$, the respective confidence interval at $95 \%$, and the determination coefficient of the curves.

\begin{tabular}{cccc}
\hline Time & IC50 $(\mu \mathbf{M})$ & Confidence Interval 95\% & $\mathbf{R}^{\mathbf{2}}$ \\
\hline $72 \mathrm{~h}$ & 162.1 & {$[129.2 ; 203.3]$} & 0.997 \\
\hline $96 \mathrm{~h}$ & 34.3 & {$[19.7 ; 59.9]$} & 0.943 \\
\hline $120 \mathrm{~h}$ & 37.3 & {$[25.1 ; 56.8]$} & 0.932 \\
\hline
\end{tabular}

\subsection{ZOL-BCP Citotoxicity}

Figure 4 shows the comparison of the metabolic activities obtained for the HGF submitted to the treatment with ZOL and with ZOL/BCP $(0.02 \mathrm{~g})$ for $48,72,96$, and $120 \mathrm{~h}$. BCP showed a significant protective effect from ZOL.

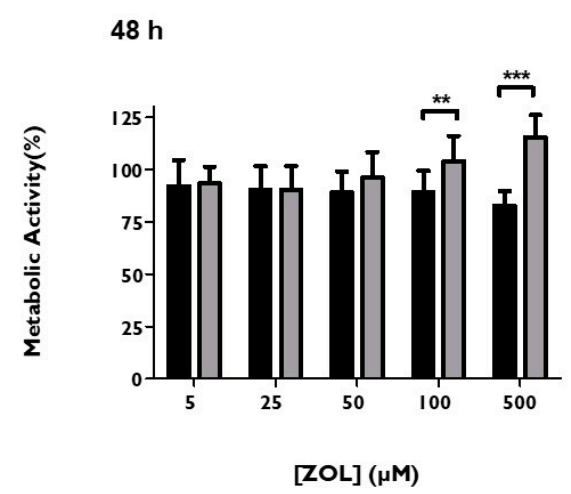

$96 \mathrm{~h}$

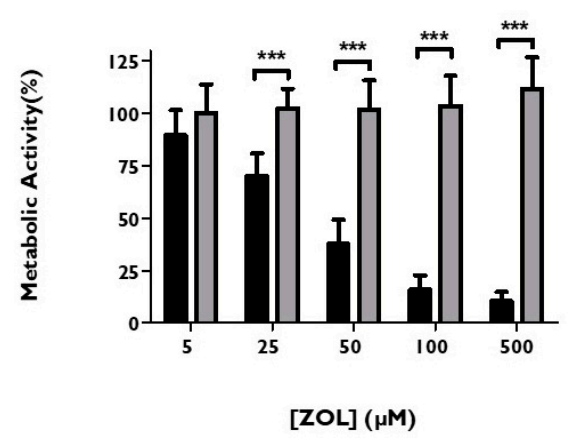

$72 \mathrm{~h}$

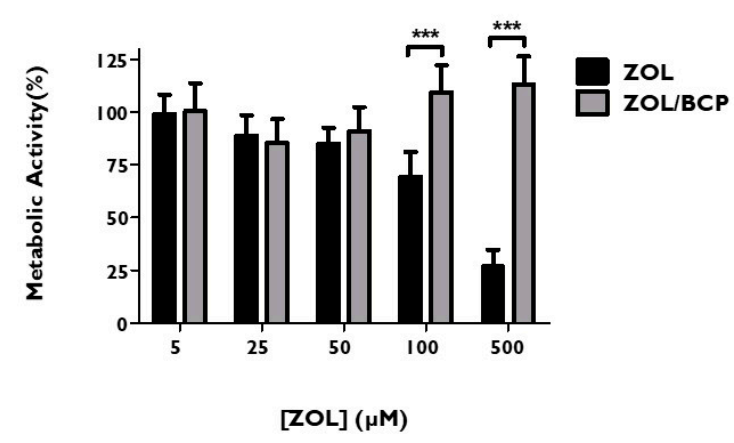

$120 \mathrm{~h}$

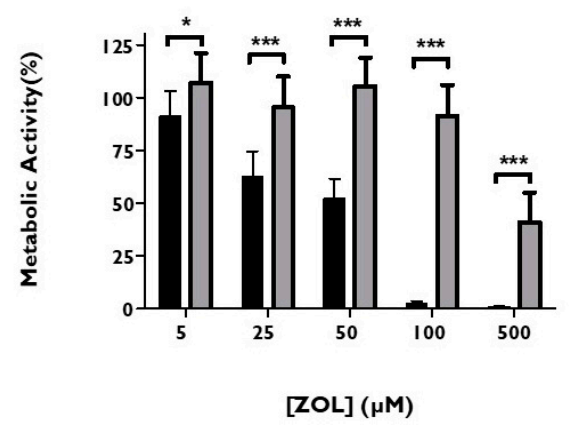

Figure 4. HGF metabolic activity, $48 \mathrm{~h}, 72 \mathrm{~h}, 96 \mathrm{~h}$ and $120 \mathrm{~h}$ after treatment with ZOL and with ZOL/BCP. The results represent the mean and standard deviation of at least six tests. Significant differences are represented with ${ }^{*}$, where ${ }^{*}$ means $p<0.05,{ }^{* *}$ means $p<0.01$, and ${ }^{* * *}$ means $p<0.001$.

After $72 \mathrm{~h}$ of incubation, a metabolic activity of $69.3 \pm 11.8 \%$ was obtained after incubation with $100 \mu \mathrm{M}$ of ZOL; with the association of $\mathrm{BCP}$, a value of $109.2 \pm 11.8 \%(p<0.001)$ was obtained. Regarding the administration of $500 \mu \mathrm{M}$ of ZOL, cellular metabolic activity reached a value of only of $26.7 \pm 8.02 \%$; however, the corresponding association with BCP maintained a value of $113.2 \pm 13.1 \%(p<0.001)$. After 
$96 \mathrm{~h}$ of ZOL incubation, the protective effect of BCP was observed for the concentrations ranging from 25 to $500 \mu \mathrm{M}$. This effect was maintained even at $120 \mathrm{~h}$ of incubation for all the concentrations of ZOL studied.

\subsection{Cell Migration Studies/Scratch Assay}

Figure 5 shows the percentage of migration of HGF cultures under the treatment with ZOL versus with ZOL/BCP. Untreated cell cultures can recover confluency in $120 \mathrm{~h}$.
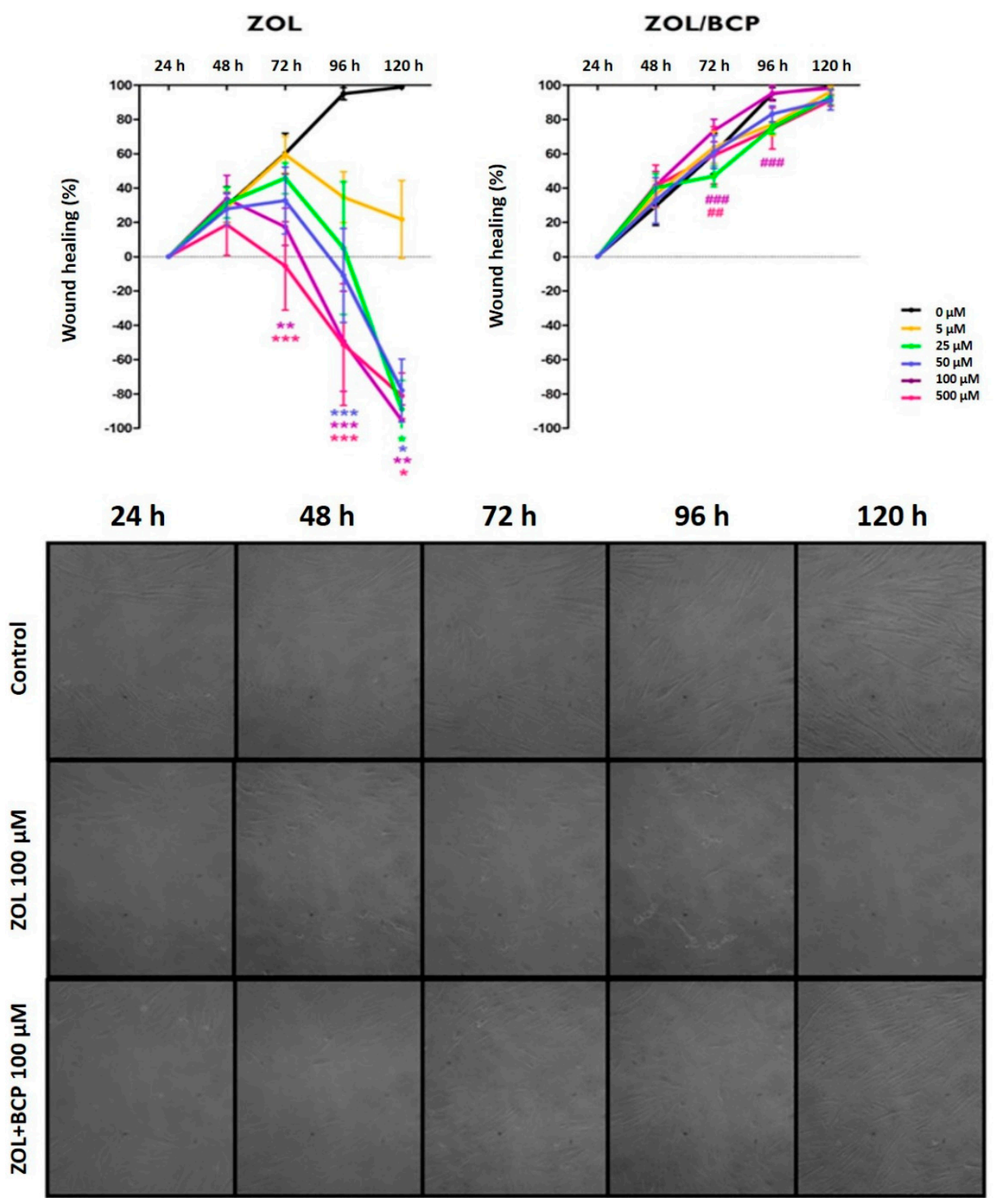

Figure 5. The migration of HGF up to $120 \mathrm{~h}$, comparing cell cultures under treatment with ZOL (left) and with $\mathrm{ZOL} / \mathrm{BCP}$ (right). The results represent the mean and standard deviation of at least three tests. Significant differences are represented with ${ }^{*}$, where ${ }^{*}$ means $p<0.05$, ${ }^{* *}$ means $p<0.01$, and ${ }^{* * *}$ means $p<0.001$. The images in the bottom of the panel are representative microphotographs of control cell cultures and cell cultures submitted to ZOL and to ZOL/BCP for $24 \mathrm{~h}, 48 \mathrm{~h}, 72 \mathrm{~h}, 96 \mathrm{~h}$ and $120 \mathrm{~h}$.

However, in cultures subjected to $\mathrm{ZOL}$, confluence recovery is compromised proportionally to concentration and is significant for higher concentrations. Thus, for the concentration of $100 \mu \mathrm{M}$, there was a lower percentage of HGF migration after $72 \mathrm{~h}(p=0.004), 96 \mathrm{~h}(p<0.001)$, and $120 \mathrm{~h}(p=0.003)$, and, for the concentration of $500 \mu \mathrm{M}$, the percentage was lower for the same time points $(p<0.001$, 
$p<0.001$ and $p=0,016$, respectively). After treatment with the lower concentrations of $50 \mu \mathrm{M}$ and $25 \mu \mathrm{M}$, the same effect was observed after $96 \mathrm{~h}(p<0.001)$ and $120 \mathrm{~h}(p<0016$ and $p=0.037$, respectively).

Nevertheless, cultures submitted to ZOL/BCP did not show any differences in HGF migration regarding untreated cell cultures. Furthermore, even cultures treated with ZOL100/BCP and ZOL500/BCP for $72 \mathrm{~h}$ showed a significantly superior closure area than those treated with ZOL at the same concentration $(p<0.001$ and $p=0.006$, respectively). Moreover, the area covered by the cells treated with ZOL $(100 \mu \mathrm{M}) / \mathrm{BCP}$ is significantly higher than the cell cultures treated with ZOL alone $(p<0.001)$ after $96 \mathrm{~h}$ of incubation.

\subsection{Viability}

Figure 6 shows HGF viability after treatment with ZOL and with ZOL/BCP $(0.02 \mathrm{~g})$. After $48 \mathrm{~h}$ of incubation, the viability of HGF treated with $\mathrm{ZOL} / \mathrm{BCP}$ was significantly higher than the cultures incubated with ZOL in the concentrations of $5 \mu \mathrm{M}(p=0.003), 25 \mu \mathrm{M}(p<0.001), 50 \mu \mathrm{M}(p<0.001)$, and $100 \mu \mathrm{M}(p<0.001)$, respectively. Regarding the incubation time of $72 \mathrm{~h}$, the viability of HGF treated with $\mathrm{ZOL} / \mathrm{BCP}$ was superior to the cultures treated with $\mathrm{ZOL}$ in the concentrations of $50 \mu \mathrm{M}$ $(p<0.001), 100 \mu \mathrm{M}(p<0.001)$, and $500 \mu \mathrm{M}(p<0.001)$. In addition, after $96 \mathrm{~h}$ and $72 \mathrm{~h}$ of incubation in the concentrations of $\mathrm{ZOL}$ where a decrease of viability was observed, there was also a significant protective effect of ZOL/BCP. This was observed after $72 \mathrm{~h}$ even with $500 \mu \mathrm{M}$, where ZOL led to a viability of only $38.9 \pm 13.2 \%$, and the incubation with ZOL/BCP displayed a value of $133.9 \pm 23.4 \%$ $(p<0.001)$. After $120 \mathrm{~h}$ of ZOL incubation, the inhibitory effect led to viabilities of $26.6 \%, 18.7 \%, 19.7 \%$, $21.6 \%$, and $14.3 \%$ for the concentrations of $5 \mu \mathrm{M}, 25 \mu \mathrm{M}, 50 \mu \mathrm{M}, 100 \mu \mathrm{M}$, and $500 \mu \mathrm{M}$, respectively, while the ZOL/BCP association led to $96.7 \%(p<0.001), 108.0 \%(p<0.001), 128.5 \%(p<0.001), 95.6 \%$ $(p<0.001)$, and $61.3 \%(p=0.002)$.

$48 \mathrm{~h}$

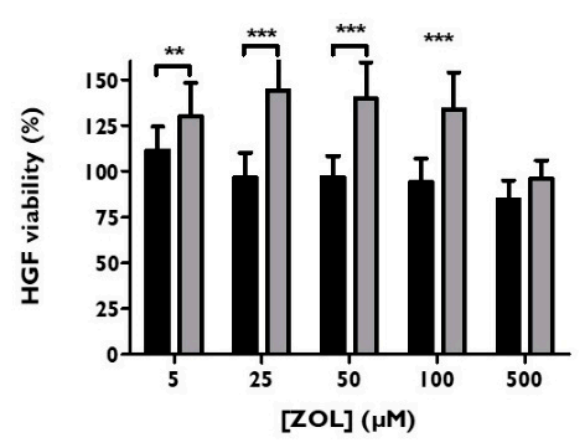

$96 \mathrm{~h}$

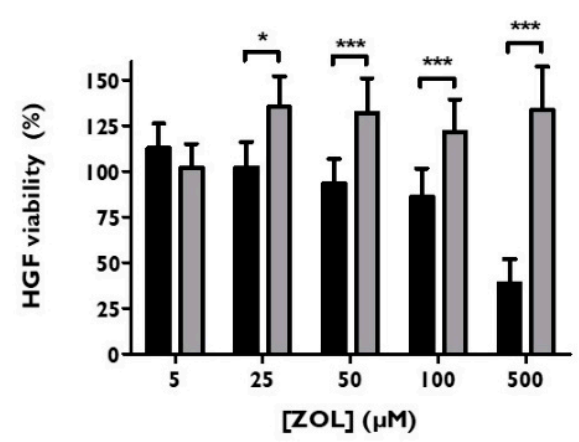

$72 \mathrm{~h}$

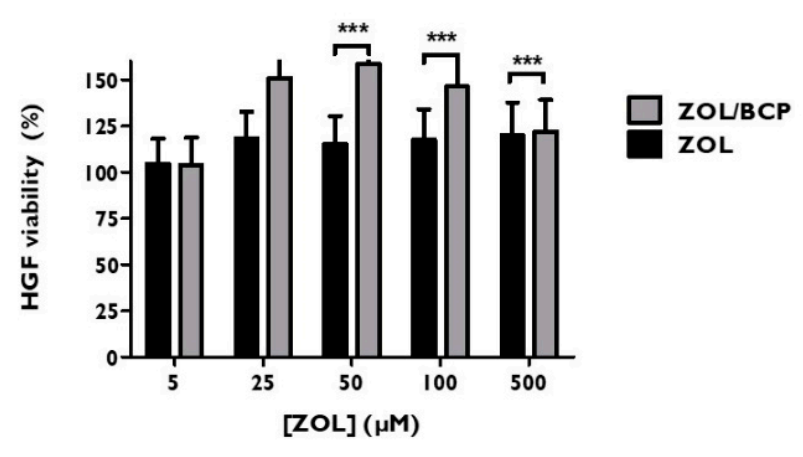

$120 \mathrm{~h}$

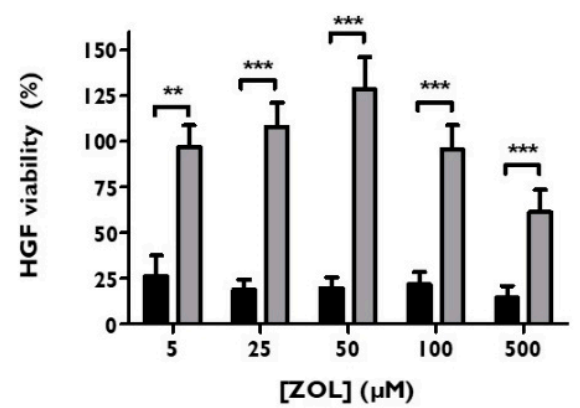

Figure 6. HGF viability, 48 h, 72 h, $96 \mathrm{~h}$ and $120 \mathrm{~h}$ after treatment with ZOL and with ZOL/BCP. The results represent the mean and standard deviation of at least six tests. Significant differences are represented with *, where ${ }^{*}$ means $p<0.05,{ }^{* *}$ means $p<0.01$, and ${ }^{* * *}$ means $p<0.001$. 


\subsection{Cell Cycle}

As can be seen in Figure 7, cells incubated with the higher ZOL concentration $(500 \mu \mathrm{M})$ were partially retained in the G0/G1 phase, with a population of $85.7 \pm 3.5 \%$ versus $66 \pm 12.5 \%(p=0.048)$ in the control. The same occurred after $120 \mathrm{~h}$ of incubation with a population of cells in the G0/G1 phase of $73 \pm 4.4 \%$, compared to the control $(56 \pm 8.7 \%, p=0.049)$. In addition to these changes, there was a pre-G0 peak both at 96 and $120 \mathrm{~h}$ that would become significant $(p<0.001)$ in the case of treatment with $500 \mu \mathrm{M}$ of ZOL.

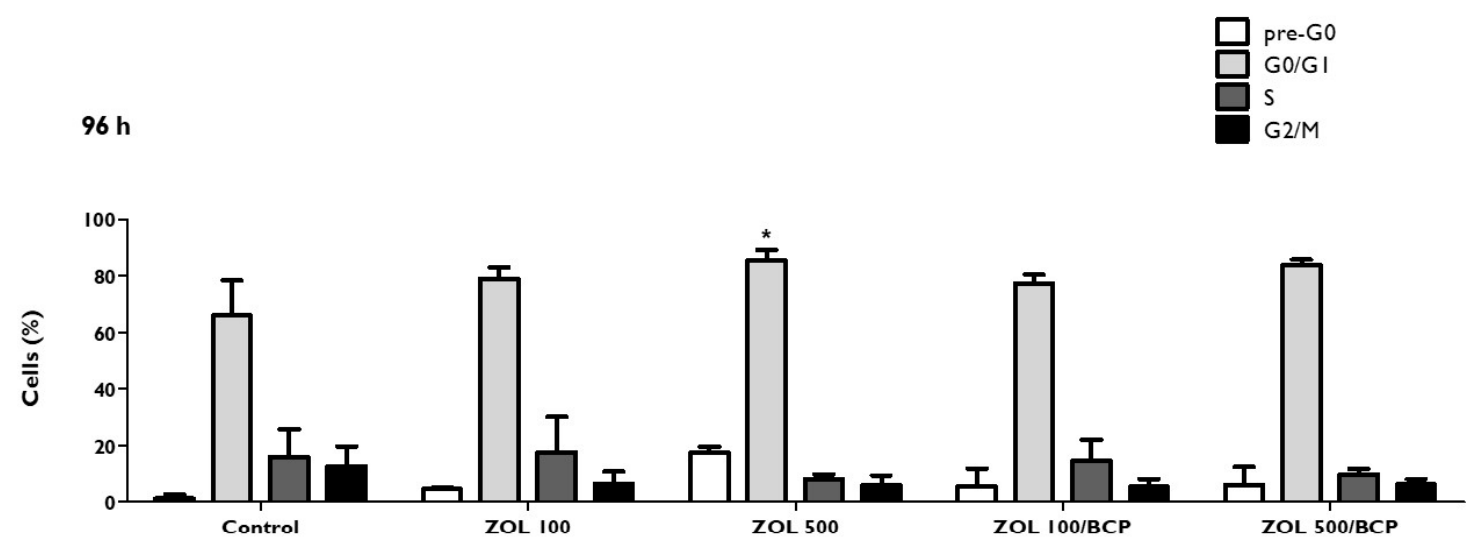

$120 \mathrm{~h}$

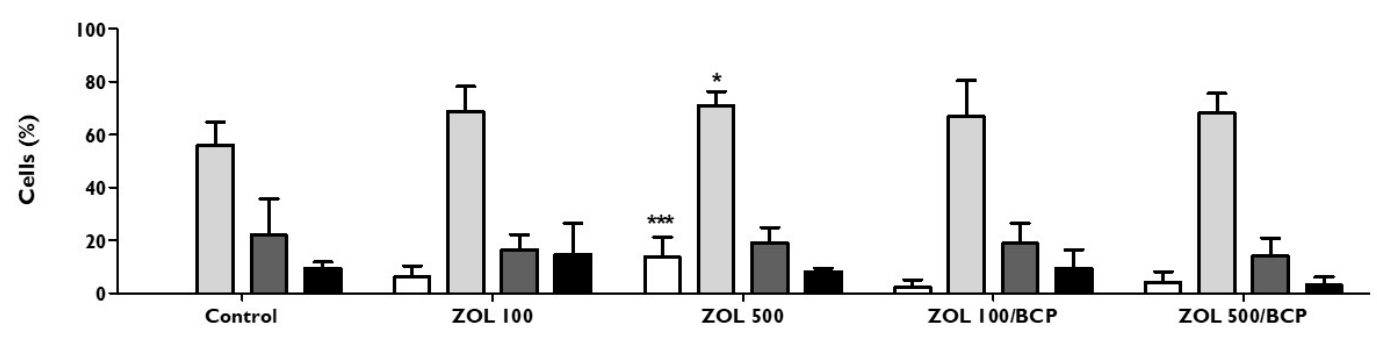

Figure 7. HGF cell cycle, $96 \mathrm{~h}$ and $120 \mathrm{~h}$ after treatment with ZOL and with ZOL/BCP. The results represent the mean and standard deviation of at least three tests. Significant differences are represented with ${ }^{*}$, where ${ }^{*}$ means $p<0.05,{ }^{* *}$ means $p<0.01$, and ${ }^{* * *}$ means $p<0.001$.

Regarding the ZOL/BCP association, the percentages of the cells are distributed through the cell cycle similarly to the control.

\subsection{Types of Cell Death}

As can be seen in Figure 8, the number of living cells and the number of apoptotic cells are influenced significantly by the exposure to ZOL. For cells incubated for $96 \mathrm{~h}$ with $100 \mu \mathrm{M}$ of ZOL (ZOL100), there was a significant decrease $(p<0.001)$ in the population of living cells from $82.6 \pm 6.6 \%$ (control cultures) to $66.5 \pm 9.9 \%$. This was accompanied by a significant increase $(p<0.001)$ of the population of cells undergoing apoptosis, from $8.4 \pm 3.8 \%$ in the control cultures to $20.3 \pm 3.7 \%$.

In the case of cells treated with $500 \mu \mathrm{M}$ of ZOL (ZOL500), there was a marked decrease in the population of living cells to $63.5 \pm 4.3 \%(p<0.001)$, as well as an increase in apoptosis $(16.9 \pm 8.4 \%$, $p=0.026)$. On the other hand, in the case of the cells treated with the combination ZOL100/BCP, there were no alterations in the various cell populations compared to the control. When the treatment was performed with a ZOL500/BCP combination, the significant decrease of the viable cell population $(p<0.01)$ was maintained; however, no significant changes in populations in apoptosis and necrosis 
were seen. The protective effect of BCP was also evidenced by the significantly lower number of viable cells treated with ZOL100 versus those treated with the ZOL100/BCP association ( $p=0.036)$.

When the evaluation was carried out after $120 \mathrm{~h}$ of incubation, there was a significant decrease in the population of living cells in both the treatment ZOL100, where there was a reduction of $81.2 \pm 5.1 \%$ to $60.7 \pm 4.7 \%(p=0.011)$, and in the treatment ZOL500, where the percentage of viable cells decreased to $48.1 \pm 5.6 \%(p<0.001)$.
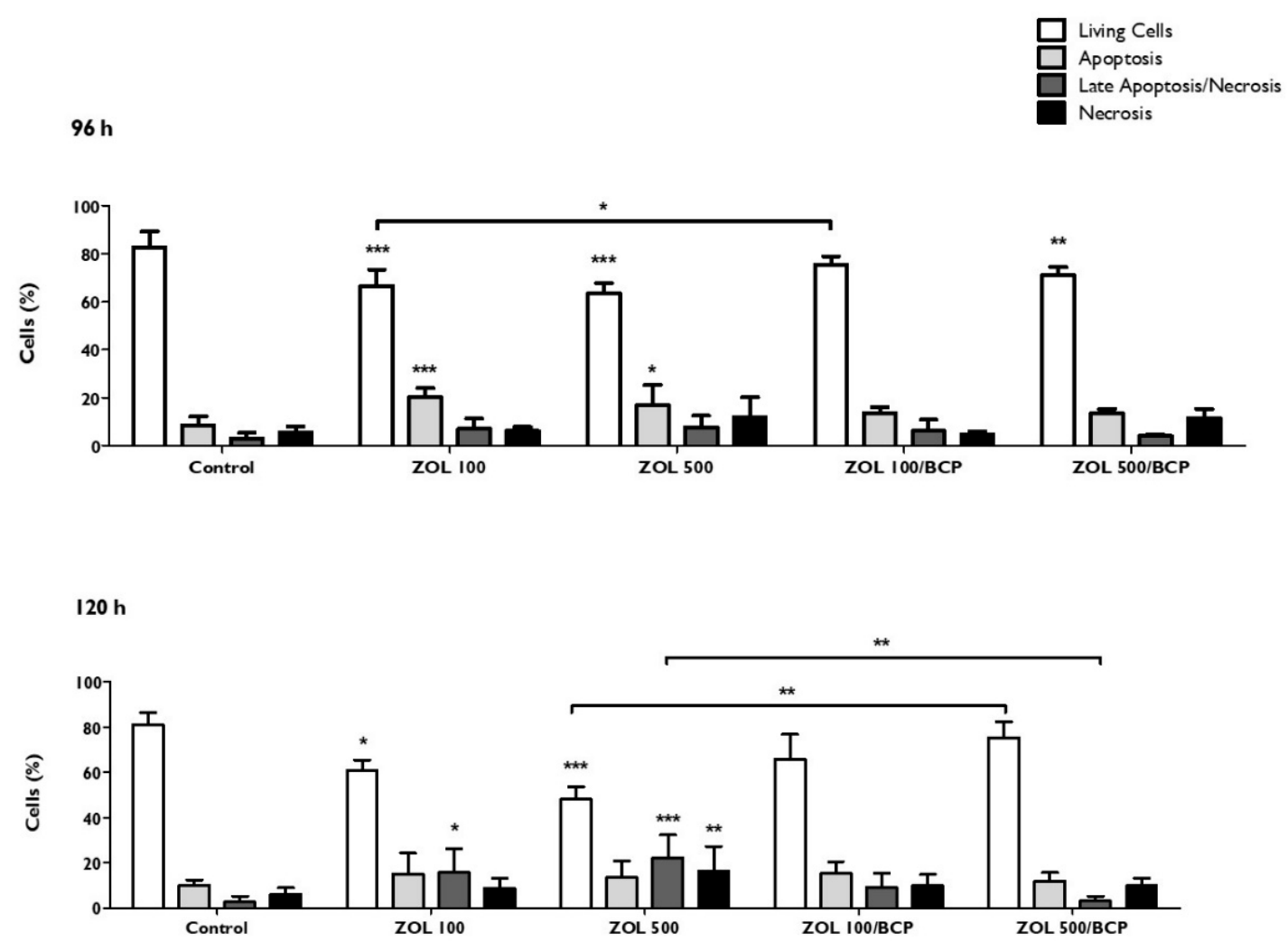

Figure 8. Types of cell death of HGF, $96 \mathrm{~h}$ and $120 \mathrm{~h}$ after treatment with ZOL and with ZOL/BCP. The results represent the mean and standard deviation of at least four tests. Significant differences are represented with *, where ${ }^{*}$ means $p<0.05{ }^{* *}$ means $p<0.01$, and ${ }^{* * *}$ means $p<0.001$.

\section{Discussion}

The pathophysiology of the osteonecrosis of the jaw (ONJ) is multifactorial. The lack of treatment options emphasizes the medical and scientific inability to define the preponderant causality. BPs inhibit osteogenic cells, osteoblasts, osteocytes, and osteoclasts [33-36], restrict angiogenesis by inhibiting endothelial cells [37], and reduce the viability of oral keratinocytes, fibroblasts, and epithelial cells, compromising oral mucosal healing [14,38-41]. These circumstances make soft tissue unable to cover the surgical wound, maintaining the exposure of the bone [16,41,42]. Continuous exposure to oral flora associated with BP-induced bone turnover maintains the inflammatory process involved in ONJ $[43,44]$.

In order to address BRONJ, we hypothesized that calcium phosphate compounds, which are used as bisphosphonate carriers for therapeutic purposes, might have a beneficial role due to their capacity to capture ZOL. To verify this, we selected two calcium phosphate ceramics, TCP and BCP, and evaluated their interaction with ZOL by UV/visible spectroscopy and by elemental analysis. The decrease in ZOL absorbance in the presence of TCP and BCP was corroborated by elemental analysis studies, where organic elements where found in BCP previously stirred with ZOL. Prior X-ray diffraction studies also proved a decrease in ZOL intensity peaks in the presence of hydroxyapatite, not due to significant 
structural change but due to a stable structural link between ZOL and hydroxyapatite [45]. Freire et al. also supported the structural adsorption of ZOL to hydroxyapatite [46].

In our study, although TCP is presented as the most effective in ZOL adsorption, it has not been ignored that this CP degrades rapidly in vivo $[47,48]$. Due to its low mechanical strength and rapid reabsorption, TCP might not be able to capture ZOL over a long time period. Therefore, we optimized a chemical reaction in which ZOL was placed in contact with $\mathrm{BCP}, \mathrm{a} \mathrm{CP}$ with superior properties, undergoing adsorption by the latter.

During healing, the proper reconstruction of soft tissues requires the coordinated interaction of keratinocytes, fibroblasts, endothelial cells, and bone marrow cells, which results in multiplication, proliferation, and migration [49,50]. Fibroblasts have a major role in filling the defect, and they provide the extracellular matrix proteins [51,52].

Therefore, HGF primary cultures were established after the collection of a gingival biopsy through the adaptations of earlier works $[20,21,53,54]$. These cells, whose morphology was evaluated routinely through the work, were used for subsequent studies.

Predictably, we observed that ZOL significantly decreased the HGF metabolic activity after $72 \mathrm{~h}$ of exposure in a manner dependent of the concentration. Earlier studies also showed ZOL cytotoxicity, not only in HGF [37,55-57] but also in oral keratinocytes [58,59], epithelial cells, and other cell types [60].

However, when HGF were exposed to ZOL-BCP, a significant protective effect was observed. The inhibitory effect of ZOL was completely reversed with the association with $\mathrm{BCP}$ in the case of exposure for 48,72 , and $96 \mathrm{~h}$ for all concentrations of ZOL tested and for $120 \mathrm{~h}$ with up to $100 \mu \mathrm{M}$ of ZOL. Hence, the evaluation of metabolic activity confirmed our hypothesis, showing that ZOL adsorption by calcium phosphate ceramics limits its cytotoxicity.

As migration is a prerequisite for fibroblasts to participate in wound healing, the remodeling of blood vessels, and tissue formation, migration and motility ability were accessed. The scratch assay is the first-line assay to evaluate healing capacity of cells subjected to a stimulus [61]. We verified that untreated HGF fill $60 \%$ of the space in $72 \mathrm{~h}$, and confluence is reached after $96 \mathrm{~h}$. As in prior studies [14,37], ZOL-treated cells' inability to close the space between edges was evident and was accompanied by cellular morphology alterations. ZOL/BCP restored the migration ability, as cultures behaved similarly to controls.

The confirmatory viability studies reinforced the cytotoxicity of ZOL. Agis and colleagues also verified the cytotoxicity of ZOL, even for gingival fibroblast cultures treated for $72 \mathrm{~h}$ [62].

After $120 \mathrm{~h}$, we found less than $25 \%$ of viability in ZOL-treated HGF cultures. However, for the same time of incubation ZOL/BCP-treated cell, viability was like the untreated control cell cultures.

During the G1 phase, cell organelles are formed, and cells grow. In the $S$ phase, self-replicating of DNA molecules occurs and in the G2 phase, and the synthesis of molecules necessary for cell division takes place [63]. We observed a slight increase of cells in the G1 phase after exposure to a high concentration of ZOL (500 $\mu \mathrm{M})$, but no alterations were found in ZOL/BCP-treated HGF. Prior studies by Manzano-Moreno and colleagues showed that the cell cycle of bisphosphonate-treated osteoblast-like cells was arrested in G1, and the percentage of cells in apoptosis was increased [64].

In order to deepen the mechanisms underlying ZOL cytotoxicity and the ZOL/BCP effect, an evaluation of types of cell death was performed. After $96 \mathrm{~h}$ of exposure to ZOL, we found an increase in the percentage of cells in apoptosis that determines a decrease in the viable cells. After $120 \mathrm{~h}$ of ZOL exposure, cell death shifts to late apoptosis $(100 \mu \mathrm{M})$ and necrosis $(500 \mu \mathrm{M})$. Apoptosis was previously indicated as a consequence of ZOL exposure in $\operatorname{HGF}[14,55,59,62,65]$ and in keratinocytes $[59,66]$. These studies reinforce $\mathrm{CP}$ ceramics' protective effect, as ZOL/BCP-treated cells did not show any significant alterations in the populations in cell death, and the decrease of cell viability was negligible. In the future, it would be interesting to further explore types of cell death and to see if senescence pathways are associated with this process.

Our results validate our hypothesis. BCP interaction with ZOL reduces or even nullifies its toxicity in HGF. This finding represents a potential solution to BRONJ in the case of patients undergoing therapy 
with ZOL. Some studies with animal models of BRONJ have already been described [67-70]. In order to verify our hypothesis in vivo, pre-clinical studies in animals are currently being performed by our group.

\section{Conclusions}

ZOL had a strong cytotoxic effect in HGF, observed by the reduction of metabolic activity, migration, and cell viability, as well as by the increase of cells in apoptosis. The ZOL/BCP association reduced or abolished ZOL toxicity, as was demonstrated by the absence of differences related to control. In the future, it would be interesting to further explore types of cell death and to see if senescence pathways are associated with this process. Nevertheless, in vivo studies are already being performed.

This work confirmed our hypothesis that $\mathrm{BCP}$, a material already used in dentistry, has a protective effect regarding ZOL cytotoxicity. BCP application in the surgical wound might capture ZOL released from the bone, decreasing its bioavailability. This finding might represent a potential solution for BRONJ in the case of patients undergoing therapy with ZOL.

Author Contributions: Conceptualization, S.P., M.L., E.C., A.S., M.F.B. and M.M.F.; data curation, S.P., J.C.-L., K.S., A.C.G., C.M.M., A.B.S.-R. and A.S.; formal analysis, A.M.A., J.C.-L. and A.B.P.; funding acquisition, A.S., M.F.B. and M.M.F.; investigation, S.P., M.L., A.M.A., A.B.P. and C.M.M.; methodology, S.P., M.L., A.M.A., K.S., A.B.P. and C.M.M.; project administration, E.C. and M.M.F.; resources, M.L., A.M.A., K.S., A.C.G. and A.B.S.-R.; Software, A.M.A., A.C.G. and A.S.; supervision, A.S., M.F.B. and M.M.F.; validation, S.P., M.L., J.C.-L., C.M.M., E.C. and M.F.B.; visualization, A.M.A., K.S. and M.M.F.; writing-original draft, S.P. and M.L.; writing-review and editing, A.M.A., A.B.P., C.M.M., M.F.B. and M.M.F.

Funding: FCT, COMPETE-FEDER (Strategic Project PEst-C/SAU/UI3282/2013 and UID/NEU/04539/2013).

Conflicts of Interest: The authors declare no conflict of interest.

\section{References}

1. Drake, M.T.; Clarke, B.L.; Khosla, S. Bisphosphonates: Mechanism of Action and Role in Clinical Practice. Mayo Clin. Proc. 2008, 83, 1032-1045. [CrossRef] [PubMed]

2. Coleman, R.E.; Lipton, A.; Costa, L.; Cook, R.J.; Lee, K.-A.; Saad, F.; Brown, J.E.; Terpos, E.; Major, P.P.; Kohno, N.; et al. Possible survival benefits from zoledronic acid treatment in patients with bone metastases from solid tumours and poor prognostic features-An exploratory analysis of placebo-controlled trials. J. Bone Oncol. 2013, 2, 70-76. [CrossRef] [PubMed]

3. Zheng, Y.; Zhou, H.; Dunstan, C.R.; Sutherland, R.L.; Seibel, M.J. The role of the bone microenvironment in skeletal metastasis. J. Bone Oncol. 2013, 2, 47-57. [CrossRef] [PubMed]

4. Weilbaecher, K.N.; Guise, T.A.; McCauley, L.K. Cancer to bone: A fatal attraction. Nat. Rev. Cancer 2011, 11, 411-425. [CrossRef] [PubMed]

5. Russell, R.G.G.; Watts, N.B.; Ebetino, F.H.; Rogers, M.J. Mechanisms of action of bisphosphonates: Similarities and differences and their potential influence on clinical efficacy. Osteoporos. Int. 2008, 19, 733-759. [CrossRef] [PubMed]

6. Maurizi, A.; Rucci, N. The Osteoclast in Bone Metastasis: Player and Target. Cancers 2018, 10, 218. [CrossRef] [PubMed]

7. Ikebe, T. Pathophysiology of BRONJ: Drug-related osteoclastic disease of the jaw. Oral Sci. Int. 2013, 10, 1-8. [CrossRef]

8. Lim, S.S.; Lee, B.; Kim, I.S.; Hwang, S.J. Differential modulation of zoledronate and etidronate in osseous healing of an extracted socket and tibia defect. Oral Surg. Oral Med. Oral Pathol. Oral Radiol. 2017, 123, 8-19. [CrossRef]

9. Sarin, J.; DeRossi, S.S.; Akintoye, S.O. Updates on bisphosphonates and potential pathobiology of bisphosphonate-induced jaw osteonecrosis. Oral Dis. 2008, 14, 277-285. [CrossRef]

10. Lesclous, P.; Abi Najm, S.; Carrel, J.-P.; Baroukh, B.; Lombardi, T.; Willi, J.-P.; Rizzoli, R.; Saffar, J.-L.; Samson, J. Bisphosphonate-associated osteonecrosis of the jaw: A key role of inflammation? Bone 2009, 45, 843-852. [CrossRef]

11. Hewitt, C.; Farah, C.S. Bisphosphonate-related osteonecrosis of the jaws: A comprehensive review. J. Oral Pathol. Med. 2007, 36, 319-328. [CrossRef] [PubMed] 
12. Kuroshima, S.; Sasaki, M.; Sawase, T. Medication-related osteonecrosis of the jaw: A literature review. J. Oral Biosci. 2019. [CrossRef] [PubMed]

13. Rollason, V.; Laverrière, A.; MacDonald, L.C.I.; Walsh, T.; Tramèr, M.R.; Vogt-Ferrier, N.B. Interventions for treating bisphosphonate-related osteonecrosis of the jaw (BRONJ). Cochrane Database Syst. Rev. 2016, 2, CD008455. [CrossRef] [PubMed]

14. Ravosa, M.J.; Ning, J.; Liu, Y.; Stack, M.S. Bisphosphonate effects on the behaviour of oral epithelial cells and oral fibroblasts. Arch. Oral Biol. 2011, 56, 491-498. [CrossRef] [PubMed]

15. Gavaldá, C.; Bagán, J.-V. Concept, diagnosis and classification of bisphosphonate-associated osteonecrosis of the jaws. A review of the literature. Med. Oral Patol. Oral Cir. Bucal 2016, 21, e260-e270. [CrossRef] [PubMed]

16. Basso, F.G.; Pansani, T.N.; Soares, D.G.; Cardoso, L.M.; Hebling, J.; de Souza Costa, C.A. Influence of bisphosphonates on the adherence and metabolism of epithelial cells and gingival fibroblasts to titanium surfaces. Clin. Oral Investig. 2018, 22, 893-900. [CrossRef] [PubMed]

17. Bose, S.; Tarafder, S. Calcium phosphate ceramic systems in growth factor and drug delivery for bone tissue engineering: A review. Acta Biomater. 2012, 8, 1401-1421. [CrossRef]

18. Verron, E.; Khairoun, I.; Guicheux, J.; Bouler, J.-M. Calcium phosphate biomaterials as bone drug delivery systems: A review. Drug Discov. Today 2010, 15, 547-552. [CrossRef]

19. Cattalini, J.P.; Boccaccini, A.R.; Lucangioli, S.; Mouriño, V. Bisphosphonate-based strategies for bone tissue engineering and orthopedic implants. Tissue Eng. Part B Rev. 2012, 18, 323-340. [CrossRef]

20. Santanna, A.C.P.; Marques, M.M.; Barroso, E.C.; Passanezi, E. Cultura e caracterização de células derivadas de ligamento periodontal humano. Rev. Fac. Odontol. 2002, 10, 134-140.

21. Saczko, J.; Dominiak, M.; Kulbacka, J.; Chwiłkowska, A.; Krawczykowska, H. A simple and established method of tissue culture of human gingival fibroblasts for gingival augmentation. Folia Histochem. Cytobiol. 2008, 46, 117-119. [CrossRef] [PubMed]

22. Pereira, N.; Laranjo, M.; Casalta-Lopes, J.; Serra, A.; Pineiro, M.; Pina, J.; Melo, J.; Senge, M.; Botelho, M.; Martelo, M.; et al. Platinum(II) ring-fused chorins as near-infrared emitting oxygen sensors and photodynamic agents. ACS Med. Chem. Lett. 2017, 8, 310-315. [CrossRef] [PubMed]

23. Mosmann, T. Rapid colorimetric assay for cellular growth and survival: Application to proliferation and cytotoxicity assays. J. Immunol. Methods 1983, 65, 55-63. [CrossRef]

24. Pereira, N.A.M.; Laranjo, M.; Pina, J.; Oliveira, A.S.R.; Ferreira, J.D.; Sánchez-Sánchez, C.; Casalta-Lopes, J.; Gonçalves, A.C.; Sarmento-Ribeiro, A.B.; Piñeiro, M.; et al. Advances on photodynamic therapy of melanoma through novel ring-fused 5,15-diphenylchlorins. Eur. J. Med. Chem. 2018, 146, 395-408. [CrossRef] [PubMed]

25. Liang, C.C.; Park, A.Y.; Guan, J.L. In vitro scratch assay: a convenient and inexpensive method for analysis of cell migration in vitro. Nat. Protoc. 2007, 2, 329-333. [CrossRef] [PubMed]

26. Otto, S.; Pautke, C.; Opelz, C.; Westphal, I.; Drosse, I.; Schwager, J.; Bauss, F.; Ehrenfeld, M.; Schieker, M. Osteonecrosis of the jaw: Effect of bisphosphonate type, local concentration, and acidic milieu on the pathomechanism. J. Oral Maxillofac. Surg. 2010, 68, 2837-2845. [CrossRef]

27. Santos, K.; Laranjo, M.; Abrantes, A.M.; Brito, A.F.; Gonçalves, C.; Sarmento Ribeiro, A.B.; Botelho, M.F.; Soares, M.I.L.; Oliveira, A.S.R.; Pinhoe Melo, T.M.V.D. Targeting triple-negative breast cancer cells with 6,7-bis(hydroxymethyl)-1H,3H-pyrrolo[1,2-c]thiazoles. Eur. J. Med. Chem. 2014, 79, 273-281. [CrossRef]

28. Vichai, V.; Kirtikara, K. Sulforhodamine B colorimetric assay for cytotoxicity screening. Nat. Protoc. 2006, 1, 1112-1116. [CrossRef]

29. Serra, A.C.; Gonsalves, A.M.D.A.R.; Laranjo, M.; Abrantes, A.M.; Gonçalves, A.C.; Sarmento-Ribeiro, A.B.; Botelho, M.F. Synthesis of new 2-galactosylthiazolidine-4-carboxylic acid amides. Antitumor evaluation against melanoma and breast cancer cells. Eur. J. Med. Chem. 2012, 53, 398-402. [CrossRef]

30. Kim, K.H.; Sederstrom, J.M. Assaying Cell Cycle Status Using Flow Cytometry. In Current Protocols in Molecular Biology; John Wiley \& Sons, Inc.: Hoboken, NJ, USA, 2015.

31. Rieger, A.M.; Nelson, K.L.; Konowalchuk, J.D.; Barreda, D.R. Modified Annexin V/Propidium Iodide Apoptosis Assay For Accurate Assessment of Cell Death. J. Vis. Exp. 2011, 50, e2597. [CrossRef]

32. Laranjo, M.; Serra, A.C.; Abrantes, M.; Piñeiro, M.; Gonçalves, A.C.; Casalta-Lopes, J.; Carvalho, L.; Sarmento-Ribeiro, A.B.; Rocha-Gonsalves, A.; Botelho, F. 2-Bromo-5-hydroxyphenylporphyrins for photodynamic therapy: Photosensitization efficiency, subcellular localization and in vivo studies. Photodiagnosis Photodyn. Ther. 2013, 10, 51-61. [CrossRef] [PubMed] 
33. J Roelofs, A.; Thompson, K.; Ebetino, F.H.; Rogers, M.J.; Coxon, F.P. Bisphosphonates: Molecular mechanisms of action and effects on bone cells, monocytes and macrophages. Curr. Pharm. Des. 2010, 16, 2950-2960. [CrossRef]

34. Açil, Y.; Möller, B.; Niehoff, P.; Rachko, K.; Gassling, V.; Wiltfang, J.; Simon, M.J.K. The cytotoxic effects of three different bisphosphonates in-vitro on human gingival fibroblasts, osteoblasts and osteogenic sarcoma cells. J. Craniomaxillofac. Surg. 2012, 40, e229-e235. [CrossRef] [PubMed]

35. Reinholz, G.G.; Getz, B.; Pederson, L.; Sanders, E.S.; Subramaniam, M.; Ingle, J.N.; Spelsberg, T.C. Bisphosphonates directly regulate cell proliferation, differentiation, and gene expression in human osteoblasts. Cancer Res. 2000, 60, 6001-6007. [PubMed]

36. Kimachi, K.; Kajiya, H.; Nakayama, S.; Ikebe, T.; Okabe, K. Zoledronic acid inhibits RANK expression and migration of osteoclast precursors during osteoclastogenesis. Naunyn. Schmiedebergs. Arch. Pharmacol. 2011, 383, 297-308. [CrossRef] [PubMed]

37. Walter, C.; Klein, M.O.; Pabst, A.; Al-Nawas, B.; Duschner, H.; Ziebart, T. Influence of bisphosphonates on endothelial cells, fibroblasts, and osteogenic cells. Clin. Oral Investig. 2010, 14, 35-41. [CrossRef] [PubMed]

38. Landesberg, R.; Cozin, M.; Cremers, S.; Woo, V.; Kousteni, S.; Sinha, S.; Garrett-Sinha, L.; Raghavan, S. Inhibition of oral mucosal cell wound healing by bisphosphonates. J. Oral Maxillofac. Surg. 2008, 66, 839-847. [CrossRef] [PubMed]

39. Kyrgidis, A.; Triaridis, S.; Antoniades, K. Effects of bisphosphonates on keratinocytes and fibroblasts having a role in the development of osteonecrosis of the jaw. Biosci. Hypotheses 2009, 2, 153-159. [CrossRef]

40. Hasegawa, T.; Ri, S.; Umeda, M.; Komatsubara, H.; Kobayashi, M.; Shigeta, T.; Yoshitomi, I.; Ikeda, H.; Shibuya, Y.; Asahina, I.; et al. The observational study of delayed wound healing after tooth extraction in patients receiving oral bisphosphonate therapy. J. Craniomaxillofac. Surg. 2013, 41, 558-563. [CrossRef] [PubMed]

41. George, E.L.; Lin, Y.-L.; Saunders, M.M. Bisphosphonate-related osteonecrosis of the jaw: A mechanobiology perspective. Bone Rep. 2018, 8, 104-109. [CrossRef]

42. Holtmann, H.; Lommen, J.; Kübler, N.R.; Sproll, C.; Rana, M.; Karschuck, P.; Depprich, R. Pathogenesis of medication-related osteonecrosis of the jaw: A comparative study of in vivo and in vitro trials. J. Int. Med. Res. 2018, 46, 4277-4296. [CrossRef] [PubMed]

43. Paulo, S.; Abrantes, A.M.; Laranjo, M.; Carvalho, L.; Serra, A.; Botelho, M.F.; Ferreira, M.M. Bisphosphonate-related osteonecrosis of the jaw: Specificities. Oncol. Rev. 2014, 8, 254. [CrossRef] [PubMed]

44. Kumar, V.; Sinha, R.K. Bisphosphonate Related Osteonecrosis of the Jaw: An Update. J. Maxillofac. Oral Surg. 2014, 13, 386-393. [CrossRef] [PubMed]

45. Boanini, E.; Torricelli, P.; Gazzano, M.; Fini, M.; Bigi, A. The effect of zoledronate-hydroxyapatite nanocomposites on osteoclasts and osteoblast-like cells in vitro. Biomaterials 2012, 33, 722-730. [CrossRef] [PubMed]

46. Freire, E.; Vega, D.R.; Baggio, R. Zoledronate complexes. III. Two zoledronate complexes with alkaline earth metals: $\left[\mathrm{Mg}\left(\mathrm{C}_{5} \mathrm{H}_{9} \mathrm{~N}_{2} \mathrm{O}_{7} \mathrm{P}_{2}\right)_{2}\left(\mathrm{H}_{2} \mathrm{O}\right)_{2}\right]$ and $\left[\mathrm{Ca}\left(\mathrm{C}_{5} \mathrm{H}_{8} \mathrm{~N}_{2} \mathrm{O}_{7} \mathrm{P}_{2}\right)\left(\mathrm{H}_{2} \mathrm{O}\right)\right]_{n}$. Acta Crystallogr. C 2010, 66, m166-m170. [CrossRef] [PubMed]

47. Daculsi, G.; Laboux, O.; Malard, O.; Weiss, P. Current state of the art of biphasic calcium phosphate bioceramics. J. Mater. Sci. Mater. Med. 2003, 14, 195-200. [CrossRef] [PubMed]

48. Nery, E.B.; LeGeros, R.Z.; Lynch, K.L.; Lee, K. Tissue response to biphasic calcium phosphate ceramic with different ratios of HA/beta TCP in periodontal osseous defects. J. Periodontol. 1992, 63, 729-735. [CrossRef] [PubMed]

49. Müssig, E.; Tomakidi, P.; Steinberg, T. Gingival fibroblasts established on microstructured model surfaces: Their influence on epithelial morphogenesis and other tissue-specific cell functions in a co-cultured epithelium: An in-vitro model. J. Orofac. Orthop. 2009, 70, 351-362. [CrossRef]

50. Ghatak, S.; Maytin, E.V.; Mack, J.A.; Hascall, V.C.; Atanelishvili, I.; Moreno Rodriguez, R.; Markwald, R.R.; Misra, S. Roles of Proteoglycans and Glycosaminoglycans in Wound Healing and Fibrosis. Int. J. Cell Biol. 2015, 2015, 1-20. [CrossRef]

51. Oberringer, M.; Meins, C.; Bubel, M.; Pohlemann, T. In vitro wounding: Effects of hypoxia and transforming growth factor $\beta 1$ on proliferation, migration and myofibroblastic differentiation in an endothelial cell-fibroblast co-culture model. J. Mol. Histol. 2008, 39, 37-47. [CrossRef] 
52. Tracy, L.E.; Minasian, R.A.; Caterson, E.J. Extracellular Matrix and Dermal Fibroblast Function in the Healing Wound. Adv. Wound Care 2016, 5, 119-136. [CrossRef] [PubMed]

53. Almeida-lopes, L.; Rigau, J.; Za, R.A. Comparison of the Low Level Laser Therapy Effects on Cultured Human Gingival Fibroblasts Proliferation Using Different Irradiance and Same Fluence. Lasers Surg. Med. 2001, 184, 179-184. [CrossRef] [PubMed]

54. João, A.Z., Jr.; Savi, L.A.; Maria, C.; Simões, O.; Coura, G.S.; Aj, Z.J.; La, S.; Cmo, S.; Protocolo, M.R.D.S.; et al. Protocolo Preliminar de Cultura de Fibroblastos Gengivais Humanos. Rev. Bras. Implantodont. Prótese sobre Implant. 2005, 12, 190-196.

55. Scheper, M.; Chaisuparat, R.; Cullen, K.; Meiller, T. A novel soft-tissue in vitro model for bisphosphonate-associated osteonecrosis. Fibrogenesis Tissue Repair 2010, 3, 6. [CrossRef] [PubMed]

56. Basso, F.G.; Pansani, T.N.; de Oliveira, C.F.; Turrioni, A.P.S.; Soares, D.G.; Hebling, J.; Costa, C.A.D.S. Cytotoxic Effects of Zoledronic Acid on Human Epithelial Cells and Gingival Fibroblasts. Braz. Dent. J. 2013, 24, 551-558. [CrossRef] [PubMed]

57. Basso, F.G.; Soares, D.G.; Pansani, T.N.; Turrioni, A.P.S.; Scheffel, D.L.; Hebling, J.; Costa, C.A.D.S. Response of a co-culture model of epithelial cells and gingival fibroblasts to zoledronic acid. Braz. Oral Res. 2016, 30. [CrossRef]

58. Kim, R.H.; Lee, R.S.; Williams, D.; Bae, S.; Woo, J.; Lieberman, M.; Oh, J.-E.; Dong, Q.; Shin, K.-H.; Kang, M.K.; et al. Bisphosphonates induce senescence in normal human oral keratinocytes. J. Dent. Res. 2011, 90, 810-816. [CrossRef]

59. Pabst, A.M.; Ziebart, T.; Koch, F.P.; Taylor, K.Y.; Al-Nawas, B.; Walter, C. The influence of bisphosphonates on viability, migration, and apoptosis of human oral keratinocytes-in vitro study. Clin. Oral Investig. 2012, 16, 87-93. [CrossRef]

60. Cornish, J.; Bava, U.; Callon, K.E.; Bai, J.; Naot, D.; Reid, I.R. Bone-bound bisphosphonate inhibits growth of adjacent non-bone cells. Bone 2011, 49, 710-716. [CrossRef]

61. Chen, B.-R.; Cheng, H.-H.; Lin, W.-C.; Wang, K.-H.; Liou, J.-Y.; Chen, P.-F.; Wu, K.K. Quiescent fibroblasts are more active in mounting robust inflammatory responses than proliferative fibroblasts. PLoS ONE 2012, 7, e49232. [CrossRef]

62. Agis, H.; Blei, J.; Watzek, G.; Gruber, R. Is zoledronate toxic to human periodontal fibroblasts? J. Dent. Res. 2010, 89, 40-45. [CrossRef] [PubMed]

63. Murray, A. Cell cycle checkpoints. Curr. Opin. Cell Biol. 1994, 6, 872-876. [CrossRef]

64. Manzano-Moreno, F.J.; Ramos-Torrecillas, J.; De Luna-Bertos, E.; Ruiz, C.; García-Martínez, O. High doses of bisphosphonates reduce osteoblast-like cell proliferation by arresting the cell cycle and inducing apoptosis. J. Cranio-Maxillofacial Surg. 2015, 43, 396-401. [CrossRef] [PubMed]

65. Zafar, S.; Coates, D.E.; Cullinan, M.P.; Drummond, B.K.; Milne, T.; Seymour, G.J. Zoledronic acid and geranylgeraniol regulate cellular behaviour and angiogenic gene expression in human gingival fibroblasts. J. Oral Pathol. Med. 2014, 43, 711-721. [CrossRef] [PubMed]

66. Ohnuki, H.; Izumi, K.; Terada, M.; Saito, T.; Kato, H.; Suzuki, A.; Kawano, Y.; Nozawa-Inoue, K.; Takagi, R.; Maeda, T. Zoledronic acid induces S-phase arrest via a DNA damage response in normal human oral keratinocytes. Arch. Oral Biol. 2012, 57, 906-917. [CrossRef] [PubMed]

67. Zandi, M.; Dehghan, A.; Malekzadeh, H.; Janbaz, P.; Ghadermazi, K.; Amini, P. Introducing a protocol to create bisphosphonate-related osteonecrosis of the jaw in rat animal model. J. Craniomaxillofac. Surg. 2016, 44, 271-278. [CrossRef]

68. Yanık, S.; Aras, M.H.; Erkılıç, S.; Bozdağ, Z.; Demir, T.; Çetiner, S. Histopathological features of bisphosphonates related osteonecrosis of the jaw in rats with and without vitamin d supplementation. Arch. Oral Biol. 2016, 65, 59-65. [CrossRef]

69. Kaibuchi, N.; Iwata, T.; Yamato, M.; Okano, T.; Ando, T. Multipotent mesenchymal stromal cell sheet therapy for bisphosphonate-related osteonecrosis of the jaw in a rat model. Acta Biomater. 2016, 42, 400-410. [CrossRef]

70. Vidal-Gutiérrez, X.; Gómez-Clavel, J.-F.; Gaitán-Cepeda, L.-A. Dental extraction following zoledronate, induces osteonecrosis in rat's jaw. Med. Oral Patol. Oral Cir. Bucal 2017, 22, e177-e184.

(C) 2019 by the authors. Licensee MDPI, Basel, Switzerland. This article is an open access article distributed under the terms and conditions of the Creative Commons Attribution (CC BY) license (http://creativecommons.org/licenses/by/4.0/). 